\title{
КОНДЕНСИРОВАННЫЕ И НЕКОНДЕНСИРОВАННЫЕ БЕНЗИМИДАЗОЛЫ КАК ПЕРСПЕКТИВНЫЕ СКАФОЛДЫ ДЛЯ МОЛЕКУЛЯРНОГО ДИЗАЙНА НОВЫХ БИОЛОГИЧЕСКИ АКТИВНЫХ СТРУКТУР
}

\author{
А.А. Спасов, В.А. Косолапов, А.Ф. Кучерявенко, О.Ю. Гречко, \\ Д.В. Мальцев, А.С. Морковник, О.Н. Жуковская, Т.А. Кузьменко, \\ Л.Н. Диваева \\ ${ }^{1}$ Кафедра фармакологии и биоинформатики, Волгоградский государственный \\ медицинский университет, 400131, Россия, Волгоград, 1, Пл. Павших Борцов. \\ ${ }^{2}$ НИИ физической и органической химии Южного федерального университета, \\ 344090, Россия, Ростов-на-Дону, пр. Стачки 194/2.
}

DOI: 10.19163/MedChemRussia2021-2021-543

E-mail:asmork@mail.ru

Ядро бензимидазола принадлежит, как известно, к так называемым привилегированным скафолдам, что обуславливает весьма многообразную биологическую активность бензимидазолов, равно как и их различных трициклических производных. В рамках проводимых исследований по синтезу и исследованию биологической активности трициклических бензимидазолов был обнаружен ряд соединений, обладающих высокой биоактивностью.

K ним, в частности, относится ряд имидазо[1,2-а]бензимидазолов: RU-254 (Diabenol; препарат для лечения диабета, пат. РФ 2061481), для которого успешно проведены все три фазы клинических исследований, а также препараты RU891 (антитромботич. действие по двумишенному механизму, пат. РФ 2696869), RU-1205 (сильный ненаркогенный анальгетик, каппа-агонист) (пат. РФ 2412187, 2413512), RU-185 (эноксифол, антиоксидант-церебропротектор (пат. РФ 2391979, 2462245). Для всех этих соединений проведен полный комплекс предклинических исследований, включая отработку их синтеза, фармакологические, токсикологические и фармацевтические исследования и подготовлена документация для получения разрешения на проведение клинический исследований.

На основе имидазо[1,2-а]бензимидазолов и других трициклических бензимидазолов получены и другие интересные биологически активные структуры, например, обладающие выраженной антигликирующей активностью, противоопухолевой активностью и т.д.

Обнаружен также новый класс соединений с выраженной анксиолитической (противотревожной) активностью, а именно, 11-R-2,3,4,5-тетрагидро[1,3] диазепино[1,2-а]бензимидазолы, среди которых найдены структуры с пониженной седативной и миорелаксирующей активностью, что интересно в плане возможности создания на их основе т.н. дневных транквилизаторов. В докладе рассмотрены также различные биологически активные структуры, найденные в ряду неконденсированных бензимидазолов. 